Amenorrhoea is rarely caused by organic disease in the hypothalamus and the pituitary, but is often associated with certain general disorders, with dietetic errors resulting in either an increase or a loss of weight, and with psychological and environmental changes.

Treatment of amenorrhoea depends on its cause, and the determination of this requires full investigation, which should generally include bacteriological examination of the endometrium to exclude tuberculosis.

The prognosis is good in cases of secondary amenorrhoea, menstruation returning in $60 \%$ of cases irrespective of treatment.

\section{REFERENCES}

Baird, I. M. (1963). Lancet, 2, 1022.

Buxton, C. L., and Herrmann, W. (1961). Amer. F. Obstet. Gynec., 81, 584

Charles, D. (1962). Lancet, 2, 278.

Barr, W., Bell, E. T., Brown, J. B., Fotherby, K., and Loraine, J. A.' (1963). Amer. F.' Obstet. Gynec., 86, 913.

Close, H. G. (1963). Lancet, 2, 1358.

Crooke, A. C., Butt, W. R., Palmer, R. F., Morris, R., Edwards, R. L., and Anson, C. L. (1963a). 7. Obstet. Gynaec. Brit. Cwlth, 70, 604 Taylor, C. W., and Short, R. V. (1963b). Brit. med. 7., 1, 1119

Carrington, S. P., Morris, R., Palmer, R. F., and Edwards, R. I (1964) Lancet, i, 184 .

Edwards, R. L. (1964). Proc. roy. Soc. Med., 57, 927.

Fienberg, R. (1963). Obstet. Gynec., 21, 687.
Finkelstein, M., Forchielli, E., and Dorfman, R. I. (1961). 7. clin. Endocr., 21, 98.

Francis, Winifred J. A. (1964a). F. Obstet. Gynaec. Brit. Cwlth, 71, 418. - (1964b). Ibid., 71, 773

Gemzell, C. A. (1963). In Modern Trends in Gynaecology, edited by R. J. Kellar, Chap. 9. Butterworth, London.

- Diczfalusy, E., and Tillinger, G. (1958). F. clin. Endocr., 18, 1333. Goldzieher, J. W., and Axelrod, L. R. (1963). Fertil. and Steril., 14, 631. - and Green, J. A. (1962). f. clin. Endocr., 22, 325.

Greenblatt, R. B. (1961). Fertil. and Steril., 12, 402.

Barfield, W. E., Jungck, E. C., and Ray, A. W. (1961). 7. Amer. med. Ass., 178, 101 .

Jacobs, P. A., Harnden, D. G., Buckton, K. E., Court Brown, W. M., King, M. J., McBride, J. A., MacGregor, T. N., and Maclean, N. (1961). Lancet, 1, 1183

Jagiello, G., and Atwell, J. D. (1962). Ibid., 1, 329.

Jeffcoate, T. N. A. (1962). Atti del Symposium internazionale su $i$ virilismi in ginecologia, p. 143. Edizione Scientifiche Salpietre, Florence, Italy.

(1964).Amer. F. Obstet. Gynec., 88, 143.

Lajos, L., Illei, G., Kecskes, L., Görcs, J., Mutschler, F., and Kobor, J. (1963). 7. Obstet. Gynaec. Brit. Cwilth, 70, 1016.

Mahesh, V. B., and Greenblatt, R. B. (1961). Nature (Lond.), 191, 888.

(1962). 7. clin. Endocr., $22,441$.

Meyer, A. S. (1955). Biochem. biophys. Acta (Amst.), 17, 441.

Prunty, F. T. G. (1956). Brit. med. F., 2, 615.

Roberts, D. W. T., and Haines, M. (1960). Ibid., 1, 1709.

Shearman, R. P."(1965). Proceedings of 7 th Australian Congress of Obstetrics and Gynaecology. In press.

Short, R. V., and London, D. R. (1961). Brit. med. F., 1, 1724

Slaunwhite, W. R., and Samuels, L. T. (1956) 7. biol. Chem., 220, 341.

Solomon, S., Vande Wiele, R., and Lieberman, S. (1956). 7. Amer. chem. Soc., 78, 5453

Sommerville, I. F, (1962). Atti del Symposium Internazionale su $i$ virilismi in ginecologia, p. 216. Edizioni Scientifiche Salpietre, Florence, Italy.

Whitelaw, M. J., Grams, L. R., and Stam, W. J. (1964). Amer. F. Obstet. Gynec., 90, 355.

\title{
Further Studies of Agents Isolated from Tissue Cultures Inoculated with Human Leukaemic Bone-marrow
}

\author{
R. J. FALLON,* M.D., B.SC., M.C.PATH. ; N. R. GRIST, † M.B., CH.B., B.SC., F.R.C.P.ED., M.C.PATH. ;
}

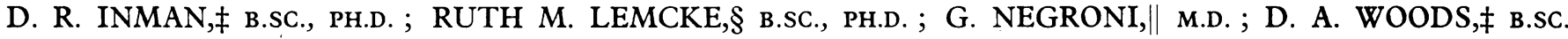

[With Special Plate]

Brit. med. F., 1965, 2, 388-391

The presence of a cytopathic agent in human-embryo-kidneycell cultures inoculated with passage fluid from human leukaemic bone-marrow was reported by Negroni (1964) and by Inman et al. (1964). The presence of a mycoplasma (pleuropneumonia-like organisms: P.P.L.O.) in these cultures has since been demonstrated by Grist and Fallon (1964) and Girardi et al. (1965). The present paper is a preliminary report of attempts to characterize this mycoplasma and to determine its relationship to the original cytopathic agent.

\section{Materials and Methods}

Tissue Cultures.-Tissue cultures of primary rhesus-monkey kidney, primary human amnion, primary human embryo, continuous baby-hamster kidney (BHK21-C13 line of Macpherson and Stoker, 1962), and the "Bristol" line of HeLa cells were prepared in Glasgow by the standard methods of the

* Department of Pathology, Ruchill Hospital, Glasgow.

† University Department of Infectious Diseases, Ruchill Hospital, Glasgow.

‡ Electron Microscopy Unit, Imperial Cancer Research Fund, London.

$\$$ The Lister Institute of Preventive Medicine, London. Present address: Department of Microbiology, Monash University, Victoria, Australia.

|| Division of Experimental Biology and Virology, Imperial Cancer Research Fund, London.
Regional Virus Laboratory, Ruchill (Grist et al., 1965) ; inoculated cultures were maintained in Eagle's medium with $1 \%$ fowl serum in order to avoid inhibitors found in calf, horse, and sheep sera.

Mycoplasma Culture Media.-The media used were those described by Lemcke (1964) or Chanock et al. (1962). Where these media were used to grow mycoplasmas for immunization of rabbits, normal rabbit serum was incorporated in the medium instead of horse serum. For the study of glucose fermentation $1 \%$ of the sugar was incorporated in the solid medium together with indicator.

Haemolysis of Mammalian Erythrocytes.-This was tested by layering blood agar on to colonies on solid medium (Somerson et al., 1963).

Serological Tests.-Tissue-culture-neutralization tests were carried out as previously described by Negroni except that the cultures were incubated stationary at $36^{\circ} \mathrm{C}$. Complementfixation (C.F.) and gel-diffusion (Ouchterlony) tests with rabbit antisera against standard strains of mycoplasma and against tissue cultures containing the cytopathic agent were performed as described by Lemcke $(1964,1965)$. C.F. tests with antiserum prepared against the mycoplasma strain $\mathrm{CW}$ were performed by a modification (Grist et al., 1965) of the method of Bradstreet and Taylor (1962) with suspensions of antigen which 


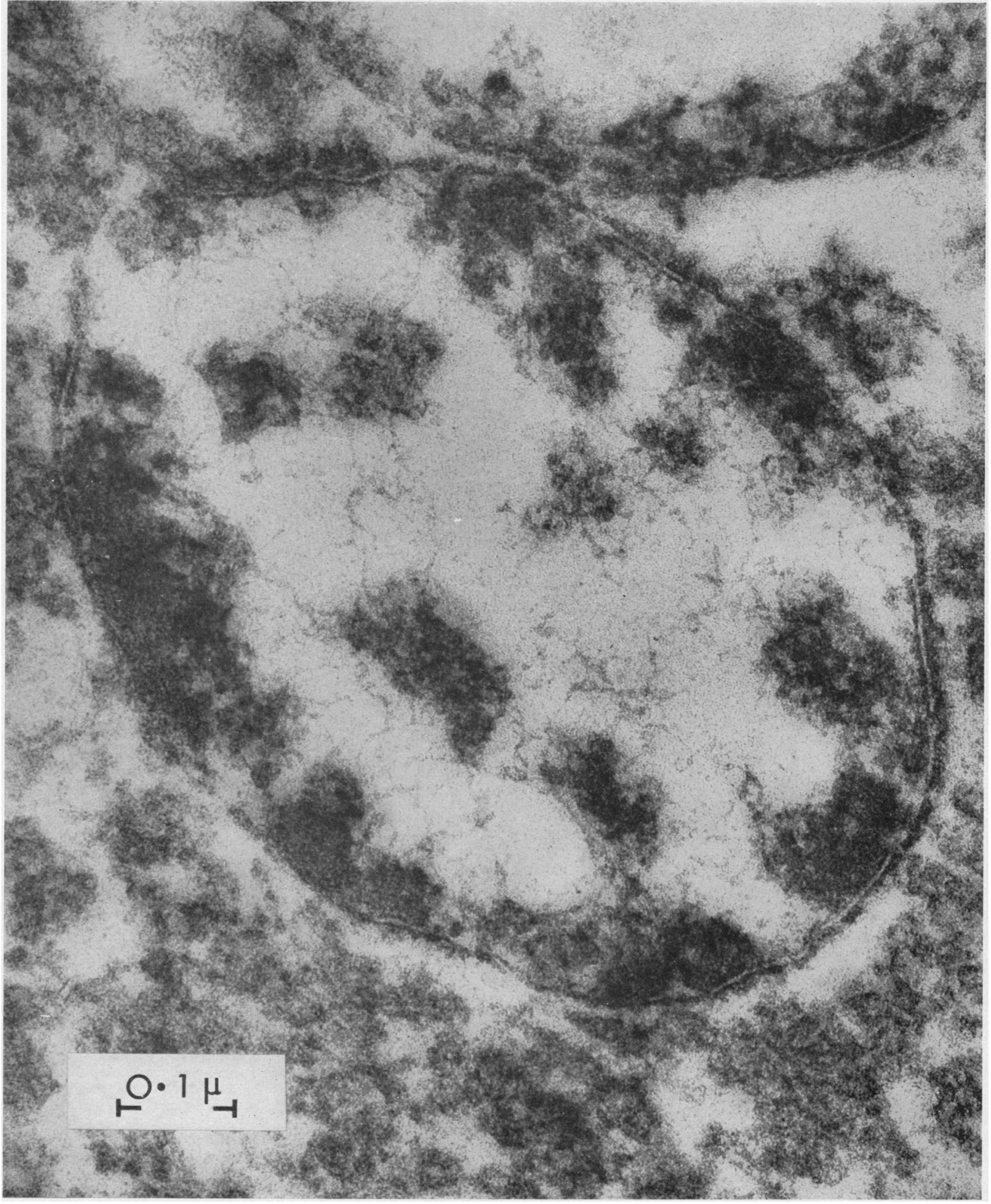

FIG. 1.-Mycoplasma in sectioned, ultracentrifuged pellet derived from broth culture infected with agent CW. Fixation: Kellenberger. 


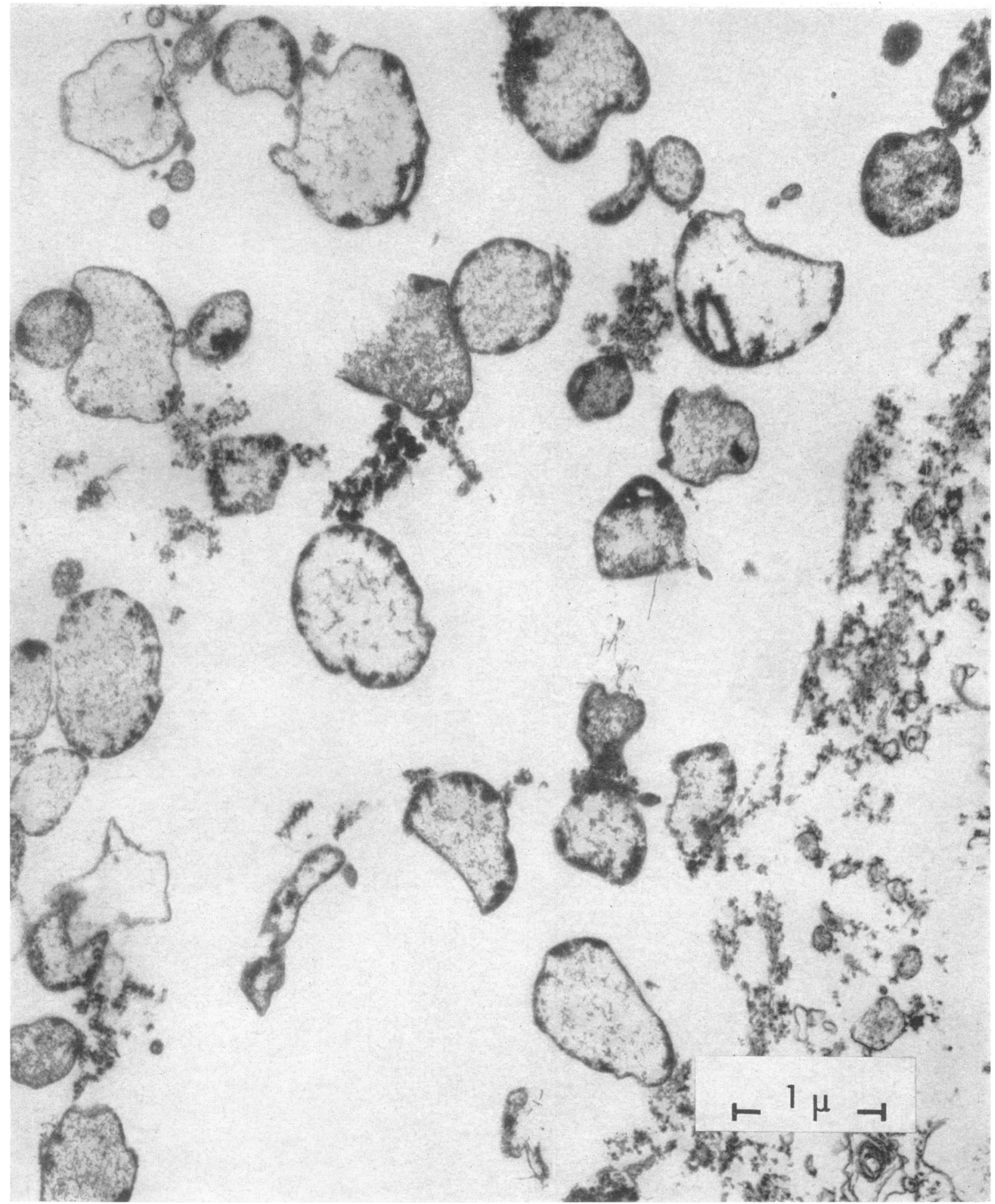

Fig. 2.-Extracellular mycoplasmas in section of human-embryo-kidney-cell culture infected with agent CW. Fixation: Palade. 


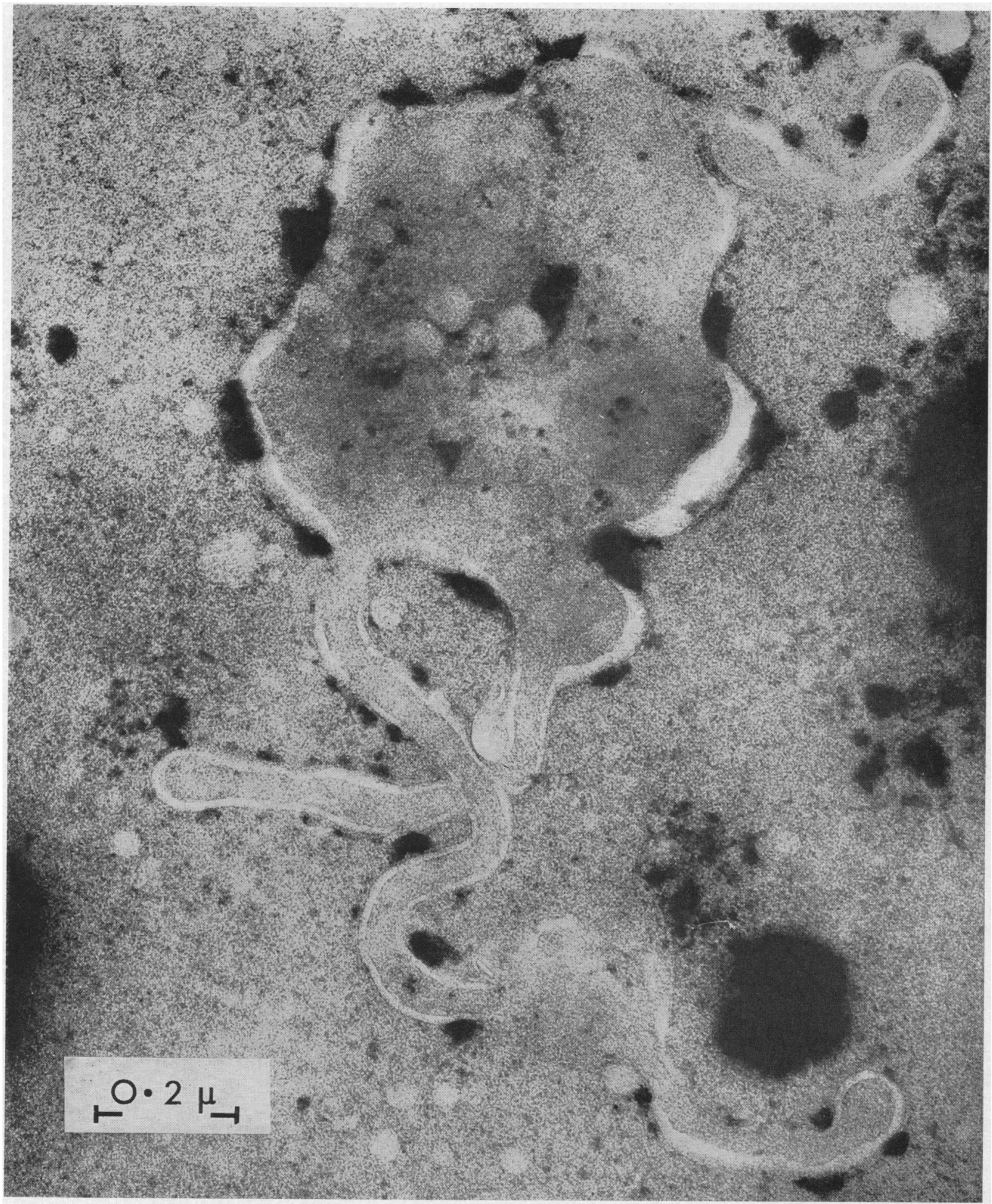

FIG. 3.-Mycoplasmas in negative contrast preparations derived from broth cultures infected with agent $\mathrm{CW}$. 


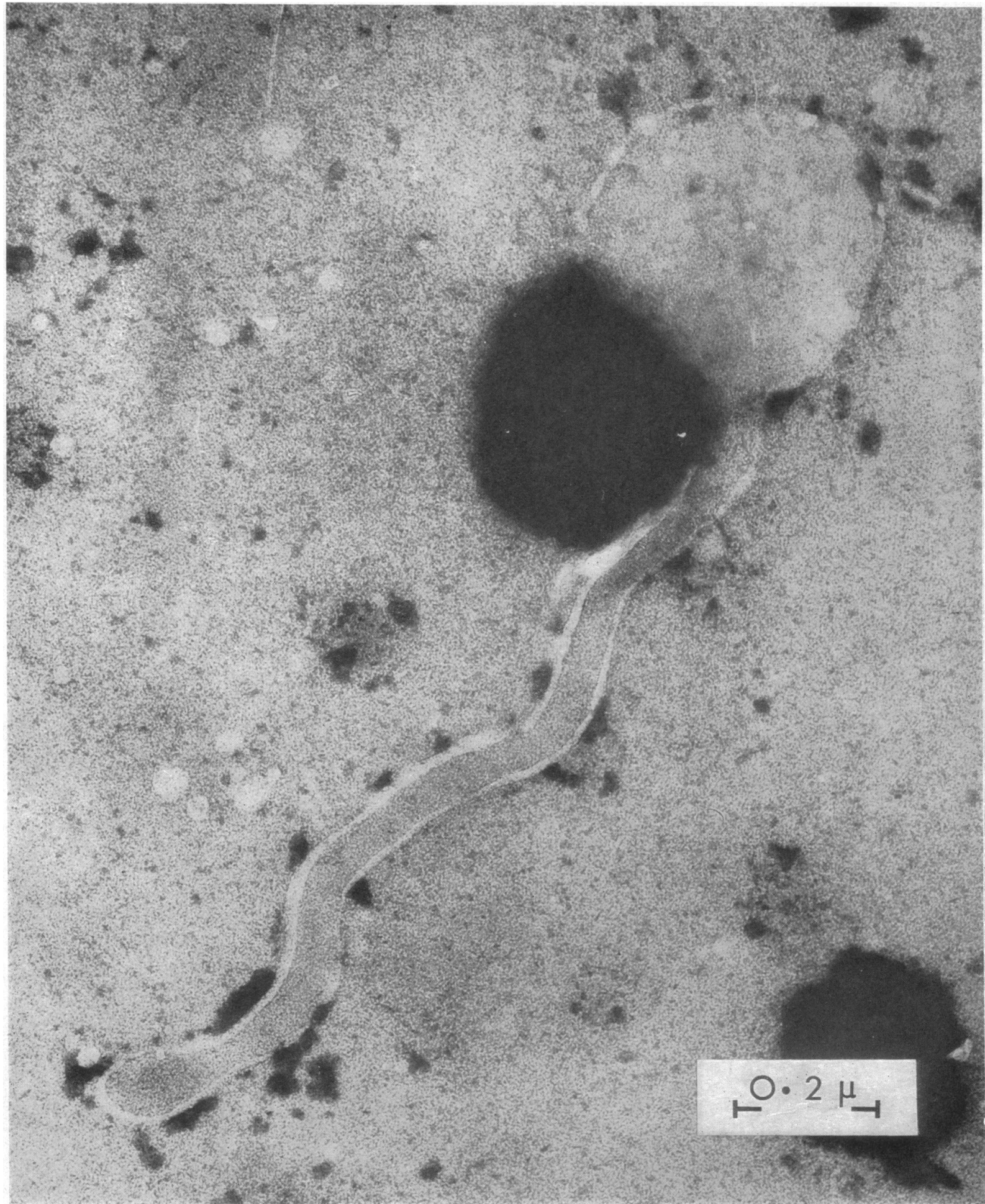

Fig. 4.-Mycoplasmas in negative contrast preparations derived from broth cultures infected with agent $\mathrm{CW}$. 
had been heated at $56^{\circ} \mathrm{C}$. for 30 minutes. Growth-inhibition tests on agar were performed by the method described by Clyde (1964), but the inoculum was adjusted to give discrete colonies.

Electron Microscopy.-The techniques used were those previously described (Inman et al., 1964) except that some preparations from broth cultures of mycoplasmas were fixed by the technique used by Kellenberger et al. (1958).

\section{Isolation of Mycoplasmas}

Material from human-embryo-tissue cultures inoculated with marrow from patient CW (Negroni, 1964) was inoculated into primary rhesus kidney, primary amnion, and continuous hamster-kidney cultures in an attempt to find a suitable system more convenient than human embryo. Transmissible cytopathic effects (C.P.E.) appeared in the inoculated rhesus-monkeykidney and hamster-kidney cultures in three to five days-that is, as quickly as in primary human-embryo cultures. The amnion cultures remained normal in appearance, but blind passage after 14 days caused C.P.E. after nine days in further cultures. The C.P.E. was basically similar in all tissues incubated in the stationary position. In monkey-kidney cultures it appeared first in the central part of the monolayer near the bottom of the tube as a granularity of the cells with retraction to form a hole in the monolayer. The effect spread peripherally from this area- with stripping of the monolayer and desquamation of cells, while the medium became very acid. Since the C.P.E. could be inhibited by $0.6 \mu \mathrm{g}$. of tetracycline, $8 \mu \mathrm{g}$. of chlortetracycline, and $1.75 \mu \mathrm{g}$. of kanamycin per ml., infected tissue-culture fluid was inoculated on to solid mycoplasma medium. After incubation at $37^{\circ} \mathrm{C}$. for seven days many typical mycoplasma colonies were seen in these cultures. A similar organism was isolated directly on solid medium from human-embryo-tissue-culture fluid derived from patient PT (Negroni, 1964) and also from a pool of human-embryo-tissueculture fluids from several isolates which was found to contain $10^{6}$ colony-forming units per $\mathrm{ml}$. Subsequently mycoplasmas were also isolated by Dr. B. E. Andrews, of the Virus Reference Laboratory, Colindale, from tissue-culture fluids derived from each of the leukaemic patients mentioned by Negroni (1964) and stored at $-70^{\circ}$ C. since 1961 . Mycoplasmas were not isolated from the control tissue cultures which have so far been examined.

Strain CW was grown on mycoplasma media and was shown to give rise to the C.P.E. described above when reinoculated into rhesus-monkey-kidney-tissue culture. The biological and serological characteristics of this strain were examined in detail. One of the strains isolated by Dr. B. E. Andrews, derived from patient IG, was compared serologically with CW by several methods. Four other of Dr. Andrews's isolates (derived from patients $\mathrm{RD}, \mathrm{KH}, \mathrm{PT}$, and from a different passage of IG) were compared in gel-diffusion tests only.

\section{Characterization of Strains of Mycoplasma}

\section{Biology}

(a) Identification as a Mycoplasma.-The organisms isolated on agar were identified as mycoplasmas on the following criteria: the colonies on solid medium had the typical "fried egg" appearance and the embedded centres could not be removed by scraping the surface of the medium with a wire loop; they stained with Diene's stain and retained the stain; they did not show bacterial forms on microscopical examination; they failed to grow in the absence of serum and did not produce bacterial forms when grown in antibiotic-free medium.

(b) Fermentation Reactions.-Both strains $\mathrm{CW}$ and IG fermented glucose, a property shared by two mycoplasmas isolated from man, $M$. pneumoniae and $M$. fermentans. (c) Haemolysis of Mammalian Erythrocytes.-Strain CW produced $\beta$-haemolysis of guinea-pig erythrocytes after 48 hours' incubation at $37^{\circ}$ C. when these were applied as a $4 \%$ overlay in P.P.L.O. agar. This property is shared only by $M$. pneumoniae of the mycoplasmas isolated from man.

(d) Antibiotic-sensitivity Pattern.-By a disk-diffusion technique the mycoplasma appeared to be sensitive to tetracycline $10 \mu \mathrm{g}$., colistin $50 \mu \mathrm{g} .$, kanamycin $10 \mu \mathrm{g}$., and chloramphenicol $10 \mu \mathrm{g}$. It was resistant to streptomycin $10 \mu \mathrm{g}$. and erythromycin $10 \mu \mathrm{g}$. On solid medium containing antibiotic the mycoplasma was found to be resistant to penicillin $500 \mu \mathrm{g} . / \mathrm{ml}$. and to cephaloridine $32 \mu \mathrm{g} . / \mathrm{ml}$.

(e) Growth in Tissue Culture.-In addition to primary - human embryo, rhesus monkey kidney, human amnion, and continuous baby-hamster kidney, Bristol HeLa cultures were also susceptible to C.P.E. caused by strain CW.

(f) Resistance.-Infectivity of fluid cultures of $\mathrm{CW}$ was destroyed by overnight refrigeration at $4^{\circ} \mathrm{C}$. with equal volumes of ether or by incubation at $44^{\circ} \mathrm{C}$. for one hour. The organism survived incubation at $41^{\circ} \mathrm{C}$. for one hour.

\section{Serology}

(a) Tests with Rabbit Antisera to Standard Strains of Mycoplasma.-The results of titrating strains CW and IG in CF tests with antisera to 17 different serological types or species of mycoplasma are shown in Table I. Strains CW and IG did not react significantly with 16 of the 18 antisera used, the level of cross-reaction being less than $1 / 32$ of the homologous titre in each case. With antisera to two strains of $M$. pulmonis, $\mathrm{Ml}$ and Kon, from rat and mouse lung respectively, both strains gave higher levels of cross-reaction. With antiserum to $\mathrm{Ml}$ they reacted to $1 / 8$ of the homologous titre and with antiserum to Kon to $1 / 2$ of the homologous titre although the latter was low (160).

TABLE I.-Complement-fixing Titres of Mycoplasmas $C W$ and IG from Tissue Cultures with Antisera to Standard Mycoplasma Strains

\begin{tabular}{|c|c|c|c|}
\hline \multirow{2}{*}{ Antiserum to } & \multirow{2}{*}{$\begin{array}{l}\text { Titre with } \\
\text { Homologous Strain }\end{array}$} & \multicolumn{2}{|c|}{ Titre with Strains } \\
\hline & & CW & IG \\
\hline 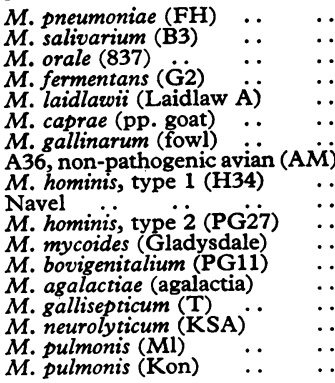 & $\begin{array}{c}2,560 \\
5,120 \\
1,280 \\
1,280 \\
2,560 \\
640 \\
2,560 \\
10,240^{*} \\
1,280 \\
160\end{array}$ & $\begin{array}{c}<20 \\
<20 \\
<20 \\
<20 \\
<20 \\
<20 \\
20 \\
80^{*} \\
160 \\
80\end{array}$ & $\begin{array}{c}20 \\
40 \\
20 \\
40 \\
20 \\
20 \\
20 \\
160^{*} \\
160 \\
80\end{array}$ \\
\hline
\end{tabular}

In gel-diffusion tests CW and IG were tested against antisera to all the species represented in Table I except $M$. pneumoniae, which did not precipitate with homologous suspensions. Both strains reacted identically and gave precipitation lines only with antisera to $\mathrm{Ml}$ and Kon. Three precipitation lines were formed in each case. Two of these seemed identical with homologous lines and one was different. Four of the other strains isolated by Dr. Andrews were indistinguishable from CW and IG in their precipitation reactions with antisera to $\mathrm{Ml}$ and Kon.

In growth-inhibition tests on solid medium, strains $C W$ and IG were inhibited by antiserum to $\mathrm{Ml}$, the inhibition zones being $2 \mathrm{~mm}$. from the edge of the disk to the rim of growth of the mycoplasma. This serum gave inhibition zones 3-5 mm. wide with $\mathrm{Ml}$ and Kon (see Table III). No tests were done with Kon antiserum. 
The results suggested that the mycoplasmas CW and IG were the same and that they were related serologically to strains of $M$. pulmonis. They were not related to 16 other serotypes or species of mycoplasma from man, rats, mice, poultry, cattle, goats, and sewage.

(b) Tests with Rabbit Antiserum HL Prepared Against Tissue Cultures Containing Cytopathic Agent.-Antiserum HL was one of the antisera prepared by Negroni (1964) to a strain of cytopathic agent derived from patient RD and used in tissueculture-neutralization tests. Strains CW and IG were titrated by C.F. tests against this antiserum and the corresponding preimmunization rabbit serum. At the same time antigens of 15 other species of mycoplasma, including $M$. pulmonis, were titrated against these two sera and against their homologous sera as controls. Only strains $\mathrm{CW}, \mathrm{IG}$, and the two strains of M. pulmonis, $\mathrm{Ml}$ and Kon, gave a rising titre with antiserum HL compared with the pre-immunization serum (Table II).

TABLE II.-Complement-fixation Tests with (a) Antiserum HL Prepared Against Tissue Cultures Containing Cytopathic Agent and (b) Antiserum Against Mycoplasma CW Grown in Broth

\begin{tabular}{|c|c|c|c|c|}
\hline \multirow[b]{2}{*}{$\begin{array}{l}\text { Antigen } \\
\text { of Strain }\end{array}$} & \multicolumn{4}{|c|}{ Titre of } \\
\hline & $\begin{array}{c}\text { Pre- } \\
\text { immunization } \\
\text { Serum } \mathrm{HL}^{*}\end{array}$ & $\begin{array}{c}\text { Antiserum } \\
\mathrm{HL}^{*}\end{array}$ & $\begin{array}{c}\text { Pre- } \\
\text { immunization } \\
\text { Serum CW }\end{array}$ & $\underset{\text { CWtiserum }}{\text { Ant }}$ \\
\hline $\begin{array}{l}\text { CW } \\
\text { IG } \\
\text { MI } \\
\text { Kon }\end{array}$ & $\begin{array}{l}<20 \\
<20 \\
20 \\
<20\end{array}$ & $\begin{array}{c}20-40 \\
20-40 \\
80 \\
80\end{array}$ & $\begin{array}{l}<20 \\
\text { NT } \\
<20 \\
<20\end{array}$ & $\begin{array}{c}1,024 \\
\text { NT } \\
256\end{array}$ \\
\hline
\end{tabular}

NT $=$ Not tested.

+ C.F.T. in tubes (Lemcke, 1964).

In growth-inhibition tests, strains $\mathrm{CW}, \mathrm{IG}$, and $\mathrm{Ml}$ were all inhibited by antiserum HL, the zone of inhibition being approximately $2 \mathrm{~mm}$. wide (Table III). The results with Kon were equivocal, with a narrow zone of inhibition surrounding disks impregnated with both immune and pre-immunization serum as well as a control disk without serum. The results suggested that the antiserum $\mathrm{HL}$, prepared against tissue cultures containing cytopathic agent, contained antibody specific for the mycoplasmas $\mathrm{CW}$ and IG. The presence of antibody to $\mathrm{CW}$ was further confirmed by neutralization tests in rhesus-monkeykidney cultures both with the tissue-culture fluids containing cytopathic agent and also with mycoplasma $\mathrm{CW}$. This serum neutralized approximately $10^{3}$ tissue-culture infective doses of each agent. TABLE III.-Inhibition of Growth of Mycoplasma Strains $C W, I G$, and
M. pulmonis by Antisera $H L, C W$, and $M l$

\begin{tabular}{|c|c|c|c|c|c|}
\hline \multirow{3}{*}{ Strain } & \multicolumn{5}{|c|}{$\begin{array}{l}\text { Zone Diameter Around Filter Paper Disks } \\
\text { Impregnated with Serum }\end{array}$} \\
\hline & \multicolumn{2}{|c|}{$\begin{array}{l}\text { Serum } \\
\text { HL }\end{array}$} & \multicolumn{2}{|c|}{$\underset{\mathrm{CW}}{\text { Serum }}$} & \multirow{2}{*}{$\frac{\begin{array}{c}\text { Serum } \\
\text { Ml }\end{array}}{\text { Immune }}$} \\
\hline & $\begin{array}{c}\text { Pre- } \\
\text { immunization }\end{array}$ & Immune & $\begin{array}{c}\text { Pre- } \\
\text { immunization }\end{array}$ & Immune & \\
\hline $\begin{array}{l}\mathrm{CW} \\
\mathrm{IG} \\
\begin{array}{l}\text { M.pulmonis } \\
\text { strains }\end{array}\end{array}\left\{\begin{array}{l}\text { Mi } \\
\text { Kon }\end{array}\right.$ & $\frac{\overline{\mathrm{NT}}}{1.5 \mathrm{~mm} .}$ & $\begin{array}{l}2.0 \mathrm{~mm} . \\
2.0 \mathrm{~mm} . \\
2.0 \mathrm{~mm} . \\
1.5 \mathrm{~mm} .\end{array}$ & $\overline{\text { NT }}$ & $\begin{array}{l}6.0 \mathrm{~mm} . \\
\mathrm{NT} \\
2.0 \mathrm{~mm} . \\
1.5 \mathrm{~mm} .\end{array}$ & $\begin{array}{l}2.0 \mathrm{~mm} . \\
2.0 \mathrm{~mm} . \\
5.0 \mathrm{~mm} . \\
3.0 \mathrm{~mm} .\end{array}$ \\
\hline
\end{tabular}

$$
\begin{aligned}
& \overline{N T}=\text { No inhibition } \\
& \text { Not tested. }
\end{aligned}
$$

The fact that two strains of $M$. pulmonis were the only other mycoplasmas which reacted with antiserum $\mathrm{HL}$ also suggested some antigenic relationship between the tissue-culture strains and $M$. pulmonis.

(c) Tests with Rabbit Antiserum Prepared Against Mycoplasma Strain $C W$ Cultivated in Broth.-This antiserum was titrated against $\mathrm{CW}$, Kon, and $M$. pneumoniae antigens by means of the C.F. test described by Grist et al. (1965) as compared with the other C.F. tests which were performed by the method of Lemcke (1964). The immune serum showed a considerable rise in titre compared with the pre-immunization serum for both $\mathrm{CW}$ and Kon, the rise for Kon being one- quarter of that for the homologous strain (Table II). There was no rise in titre for $M$. pneumoniae. In growth-inhibition tests on solid medium, strain $\mathrm{CW}$ and $M$. pulmonis strains $\mathrm{Ml}$ and Kon were inhibited by immune but not pre-immunization serum from the rabbit immunized with CW (Table III). As noted by Clyde (1964), the zone width varied with the inoculum, but those obtained with an inoculum giving discrete colonies were $6 \mathrm{~mm}$. for CW, $2 \mathrm{~mm}$. for Ml, and $1.5 \mathrm{~mm}$. for Kon.

Neutralization tests in rhesus-monkey kidney showed that the immune serum neutralized $10^{3}-10^{4}$ tissue-culture infective doses of strain C.W. and of the cytopathic agent contained in the tissue-culture fluids from which $\mathrm{CW}$ was isolated. It also neutralized pooled fluids from cultures derived from a number of leukaemic patients.

Gel-diffusion tests carried out with serum $\mathrm{CW}$ showed the formation of lines against homologous antigen, one of which seemed to be identical with the one line formed against Kon antigen.

These results agree with those observed with the other antisera and demonstrate the partial relationship of CW to $M$. pulmonis. They also show conclusively that the cytopathic effect observed in tissue cultures could be neutralized by antiserum to the mycoplasma alone.

\section{Electron Microscopy}

Electron micrographs of virus-like particles in pellets from ultracentrifuged cell cultures inoculated with passage fluid from leukaemic bone-marrow have already been published (Inman et al., 1964). Since then the mycoplasma CW has been examined electron-microscopically both in sectioned material and in negative contrast. After fixation by the technique of Kellenberger et al. (1958) typical mycoplasmas were identified in sections of pellets ultracentrifuged from broth cultures (Special Plate, Fig. 1). Abundant extracellular mycoplasmas were observed in human-embryo-kidney-cell cultures infected with the agent (Special Plate, Fig. 2).

The appearance of the mycoplasma in negative contrast preparations derived from infected broth cultures is shown in Figs. 3 and 4 (Special Plate). The size of the cells varied greatly, but they were generally between 90 and $1,000 \mathrm{~m} \mu$ in diameter. The length of the filaments was also very variable, but their diameter, with the exception of the terminal swellings, was always of the order of $75 \mathrm{~m} \mu$. In this type of preparation the cells and filaments had a limiting membrane and an outer diaphanous coat.

A fuller description of the morphology of the mycoplasma will be given in a later paper.

\section{Discussion}

The evidence presented suggests that mycoplasmas with the same biological and serological characteristics were present in all tissue cultures showing the C.P.E. described by Negroni (1964). They were present at the earliest passage examined (13th). Control preparations showed no C.P.E. Controls from the same passage experiments as those in which a C.P.E. was seen were not available for mycoplasma culture, but cultures from those later passages of control material which have so far been examined have proved negative for mycoplasmas. All the evidence to date points to the mycoplasma having been solely responsible for the C.P.E.; especially as it can be prevented by antibiotics.

The mycoplasma strains CW and IG are serologically unrelated to any mycoplasma hitherto reported as being isolated from man. There is, however, a partial antigenic similarity between $\mathrm{CW}$ and IG and the rodent mycoplasma, $M$. pulmonis. Experiments to be published elsewhere show that $M$. pulmonis can cause a C.P.E. like that of $\mathrm{CW}$ in certain types of tissue 
culture. Nevertheless these mycoplasmas are not completely identical with $M$. pulmonis, and it cannot necessarily be inferred that they are of rodent origin and hence merely contaminants, especially as serological cross-reactions between mycoplasmas of diverse origin are known to occur (Card, 1959; TaylorRobinson et al., 1963 ; Lemcke, 1964, 1965).

It may be argued that as the strain of mycoplasma isolated from each tissue culture inoculated with leukaemic bonemarrow was apparently identical with $\mathrm{CW}$ this could well represent contamination, especially as the only previously published description of a mycoplasma isolated direct from the bone-marrow of a patient with leukaemia (Hayflick and Koprowski, 1965) showed it to be completely different from CW. However, the human-embryo cells, derived from 59 embryos over a period of four years, were inoculated with marrow at different times. Furthermore, cultures inoculated with marrow from only eight leukaemic patients showed a C.P.E. and the presence of a mycoplasma, whereas cultures inoculated with bone-marrow from a further 18 cases of leukaemia and also those from 33 patients without leukaemia showed no C.P.E., nor were virus-like particles seen in those examined in the electron microscope.

Organisms seen in the electron microscope in both cell-free and human-embryo-kidney-cell cultures had morphological characteristics typical of mycoplasma (Domermuth et al., 1964). Reassessment of the electron microscope studies of the original infected human-embryo-cell cultures (Inman et al., 1964) suggests that mycoplasmas were seen but unrecognized as such. This was probably due in part to the preparative techniques employed, which were inappropriate for the preservation of mycoplasmal ultrastructure.

It is often impossible to distinguish between viral and mycoplasmal elements in electron micrographs. There is as yet no morphological evidence to show whether the small particles (average diameter $72 \mathrm{~m} \mu$ ) seen in the cytoplasm of the original infected cells and ultracentrifuged pellets (Inman et al., 1964) were in fact virus, as was originally believed, or small mycoplasmal elements. A study of the antigenic properties of these "virus-like" particles is in progress to investigate their possible association with the mycoplasma.

Finally, what is the relationship of this mycoplasma to leukaemia ? Other studies have shown thaat mycoplasmas may be isolated direct from the bone-marrow of patients with leukaemia (Hayflick and Koprowski, 1965) and from tissue cultures inoculated with leukaemic bone-marrow (Murphy et al., 1965). Moreover, it has been shown that a higher proportion of patients with leukaemia are without the blood-group-I antigen than is the case in the normal population (McGinniss et al., 1964) and that mycoplasmas may alter I receptor-sites on erythrocytes (Schmidt et al., 1965). However, the relationship between the mycoplasma isolated from tissue cultures and the disease in the patients whose bone-marrow was inoculated into these tissue cultures remains obscure. If the mycoplasma originated in the bone-marrow it may be quite unrelated to the patients' disease, or it may be secondary and represent infection due to failure in the patients' defence mechanisms. Finally, the mycoplasma infection could form part of a sequence of events which, in some individuals, is. associated with the development of leukaemia.

\section{Summary}

Mycoplasmas were isolated from tissue cultures inoculated with bone-marrow from leukaemic patients.

All cultures which showed a cytopathic effect contained mycoplasmas.

There was no evidence of mycoplasmas in control cultures.

The mycoplasmas isolated seemed biologically and serologically to be of one strain which was different from any previously reported as being isolated from human sources although there was some relationship to a rodent mycoplasma, $M$. pulmonis.

Mycoplasmas cannot readily be distinguished from viruses electron-microscopically.

The relationship of mycoplasmas to leukaemia is not yet clear.

We thank Dr. B. E. Andrews, of the Virus Reference Laboratory, Central Public Health Laboratory, Colindale, for examining tissue cultures inoculated with leukaemic marrow and for providing us with subcultures of the mycoplasmas isolated therefrom.

\section{REFERENCES}

Bradstreet, C. M. P., and Taylor, C. E. D. (1962). Mth. Bull. Minist. Hlth Lab. Serv., 21, 96.

Card, D. H. (1959).' Brit. F. vener. Dis., 35, 27.

Chanock, R. M., James, W. D., Fox, H. H., Turner, H. C., Mufson, M. A., and Hayflick, L. (1962). Proc. Soc. exp. Biol. (N.Y.), 110, 884.

Clyde, W. A. (1964). f. Immunol., 92, 958.

Domermuth, C. H., Nielsen, M. H., Freundt, E. A., and Birch-Andersen, A. (1964). ₹. Bact., 88, 727.

Girardi, A. J., Hayflick, L., Lewis, A. M., and Somerson, N. L. (1965). Nature (Lond.), 205, 188.

Grist, N. R., and Fallon, R. J. (1964). Brit. med. F., 2, 1263.

Ross, C. A. C., Bell, E. J., and Stott, E. J. (1965). In Diagnostic Methods in Clinical Virology. Blackwell, London. In press.

Hayflick, L., and Koprowski, H. (1965). Nature (Lond.), 205, 713.

Inman, D. R., Woods, D. A., and Negroni, G. (1964). 'Brit. med. F., 1, 929.

Kellenberger, E., Ryter, A., and Séchaud, J. (1958). F. biophys. biochem. Cytol., 4, 671.

Lemcke, R. M. (1964). F. Hyg. (Lond.), 62, 199.

Lemcke, R. M. (1964). F. Hyg. (Lond.),

McGinniss, M. H., Schmidt, P. J., and Carbone, P. P. (1964). Nature (Lond.), 202, 606.

Macpherson, I., and Stoker, M. G. P. (1962). Virology, 16, 147

Murphy, W. H., Furtado, D., and Plata, E. (1965). F. Amer. med. Ass., 191, 110

Negroni, G. (1964). Brit. med. f., 1, 927.

Schmidt, P. J., Barile, M. F., and McGinniss, M. H. (1965). Nature (Lond.), 205, 371 .

Somerson, N. L., Taylor-Robinson, D., and Chanock, R. M. (1963). Amer. f. Hyg., 77, 122.

Taylor-Robinson, D., Somerson, N. L., Turner, H. C., and Chanock, R. M. (1963). F. Bact., 85, 1261 . 